\title{
Interleukin-18 Induces Rheumatoid Arthritis Synovial Fibroblast CXC Chemokine Production through NF $\kappa$ B Activation
}

\author{
Jacques C. M. Morel, Christy C. Park, Pawan Kumar, and Alisa E. Koch \\ Department of Medicine (JCMM, CCP, PK, AEK), Northwestern University Medical School, Chicago; and Lakeside \\ Division (CCP, AEK), Veterans Administration Chicago Health Care System, Chicago, Illinois
}

\begin{abstract}
SUMMARY: Interleukin-18 (IL-18) is a novel proinflammatory cytokine that was recently found in synovial fluids and in synovial tissues from patients with rheumatoid arthritis (RA). To determine the participation of IL-18 in the inflammation observed in RA, we investigated the effect of IL-18 on RA synovial fibroblast chemokine production. Using FACS analysis, we showed that IL-18 induced a doubling in the production of intracellular IL-8 by RA synovial fibroblasts, and this result was confirmed by Western blot. At the extracellular level, IL-18 up-regulated the secretion of IL-8 in a dose- and time-dependent manner. IL-18 also up-regulated the other CXC chemokines, epithelial-neutrophil activating protein (ENA-78) and growth-regulated oncogene (gro $\alpha$ ), in a dose dependent manner, but failed to induce the production of the CC chemokine, macrophage inflammatory protein (MIP)-1 $\alpha$. By immunofluorescence and Western blot, we demonstrated that IL-18 activates the translocation of the transcription factor nuclear factor kappa $\mathrm{B}(\mathrm{NF} \kappa \mathrm{B})$ into the nucleus of RA synovial fibroblasts. IL-18 induces IL-8 secretion through NF $\kappa \mathrm{B}$ because RA synovial fibroblasts pretreated with antisense to NFKB p65 oligonucleotide produce a mean of $44 \%$ less IL-8 compared with cells pretreated with the control sense oligonucleotide. These results indicate a novel role for IL-18 in inducing RA synovial fibroblast expression of $\mathrm{CXC}$ chemokines through $\mathrm{NF} \kappa \mathrm{B}$ and place this cytokine in a strategic role in the local inflammation observed in RA. (Lab Invest 2001, 81:1371-1383).
\end{abstract}

C hemokines are low-molecular-weight cytokines that attract leukocytes through a series of coordinated biochemical and cellular events (Baggiolini et al, 1997). These chemotactic cytokines can be divided into four groups ( $\mathrm{CXC}, \mathrm{CC}, \mathrm{C}$, and $\mathrm{CX}_{3} \mathrm{C}$ ) according to the position of the first two closely paired and highly conserved cysteins of the amino acid sequence (Szekanecz et al, 1998).

In rheumatoid arthritis (RA), a chronic inflammatory disease characterized by synovial hyperplasia and leukocyte infiltration, there is abundant evidence that chemokines participate in the recruitment of the leukocytes into the RA synovial membrane (Koch et al, 1996). In the RA joint, chemokines are expressed in synovial fluids and also in synovial tissues, especially in the synovial lining layer. The fibroblasts that compose this lining layer with the macrophages are a major source of chemokines, particularly when stimulated with proinflammatory cytokines like interleukin-1 $\beta$ (IL-1 $\beta$ ) or tumor necrosis factor- $\alpha$ (TNF- $\alpha$ ).

Received May 2, 2001.

JCMM and CCP contributed equally to this work. This work was supported by National Institutes of Health Grants HL58695 and AI40987; the Gallagher Professorship for Arthritis Research; funds from the Veterans Administration Research Service; and a grant from the French nonprofit organization, Groupe d'Études et de Recherches Immuno-Rhumatologiques (GERIR).

Address reprint requests to: Dr. Alisa E. Koch, Northwestern University Medical School, Department of Medicine, 303 E. Chicago Avenue, Ward Building 3-315 Chicago, IL 60611. E-mail:ae-koch@northwestern.edu
Interleukin-18 (IL-18) is a novel cytokine structurally related to $\mathrm{IL}-1 \beta$ and is, therefore, considered a member of the IL-1 cytokine family (Bazan et al, 1996). Activated macrophages were the first cells shown to express high levels of IL-18 (Okamura et al, 1995). Further investigations revealed that IL-18 was also produced by various types of cells, such as osteoblasts, articular chondrocytes, keratinocytes, and synovial fibroblasts (Gracie et al, 1999; Naik et al, 1999; Olee et al, 1999; Udagawa et al, 1997). Like IL-1 $\beta$, IL-18 is first synthesized as a precursor molecule (pro $\mathrm{IL}-18)$ that contains a signal peptide and requires the IL-1 $\beta$ converting enzyme (ICE, caspase 1) for cleavage into the active and mature protein (Fantuzzi and Dinarello, 1999). The secreted IL-18 recognizes a heterodimeric receptor consisting of two amino acid chains that are also members of the $\mathrm{IL}-1$ receptor family (Torigoe et al, 1997). The ligand binding IL-18R chain, now termed IL-18R $\alpha$, was initially described as the IL-1 receptor binding protein. The IL-18R $\beta$ chain is similar to the IL-1 accessory protein and induces signal transduction. The signaling pathways that follow the binding of IL-18 to its receptor are not completely known. The IL-18 receptor is expressed on $\mathrm{T}$ and $B$ lymphocytes, natural killer (NK) cells (Yoshimoto et al, 1998), RA macrophages (Gracie et al, 1999), and fibroblast-like cells (Moeller et al, 1999). IL-18 functions to stimulate $\mathrm{Th}_{1}$ cytokines, such as interferon gamma (IFN $\gamma$ ), TNF- $\alpha$, and granulocyte-macrophage colony stimulating factor (GM-CSF), by T lymphocytes and NK cells (Takeda et al, 1998). IL-18 was recently 
detected in synovial fluid derived from RA patients at concentrations as high as those of TNF- $\alpha$ (Gracie et al, 1999). Additionally, IL-18 was found in the synovium within and adjacent to lymphocytic aggregates and also in the lining layer. Macrophages derived from this lining layer produce inflammatory mediators when stimulated with IL-18. Little is known about the immune effects of IL-18 on RA synovial fibroblasts. These cells, which are intimately located in proximity to the macrophages, participate in the synovial inflammation and the cartilage destruction by releasing mediators of inflammation and matrix-degrading enzymes. Therefore, we examined the effect of IL-18 on RA synovial fibroblast chemokine production. In this study, we showed that IL-18 independently promotes the production of CXC chemokines through a direct effect on synovial fibroblasts. We report evidence for the significance of the nuclear factor kappa B (NF $\kappa$ B) pathway in IL-18-induced chemokine expression.

\section{Results}

\section{Intracellular IL-8 Is Up-Regulated in IL-18-Stimulated RA Synovial Fibroblasts}

To evaluate intracellular IL-8 production, we performed FACS analysis on RA synovial fibroblasts from six patients with $R A$. Figure $1 A$ is a representative example of the flow cytometry data. The left panel corresponds to the histogram obtained for RA synovial

A

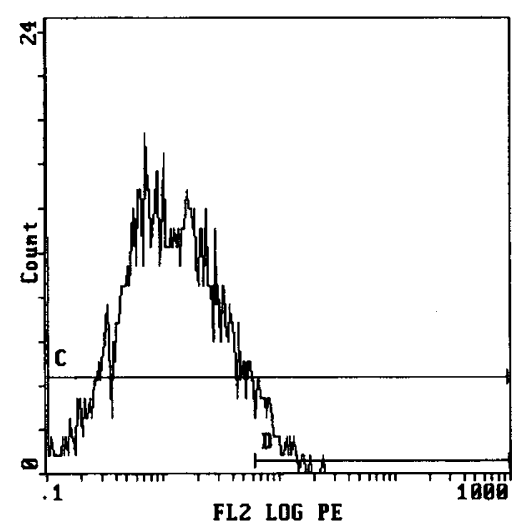

NS

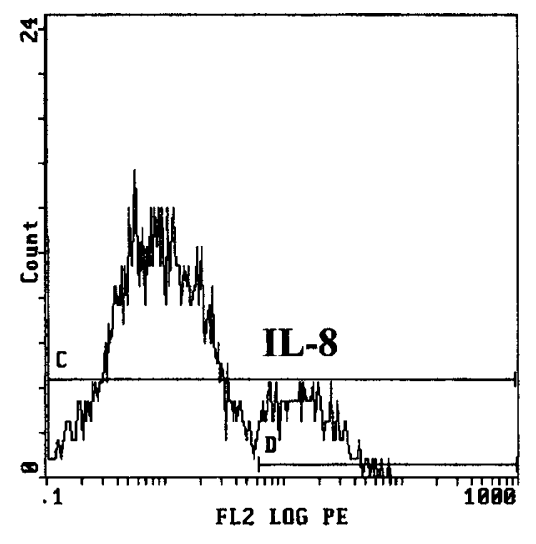

IL-18 (5 nM)

\section{B}

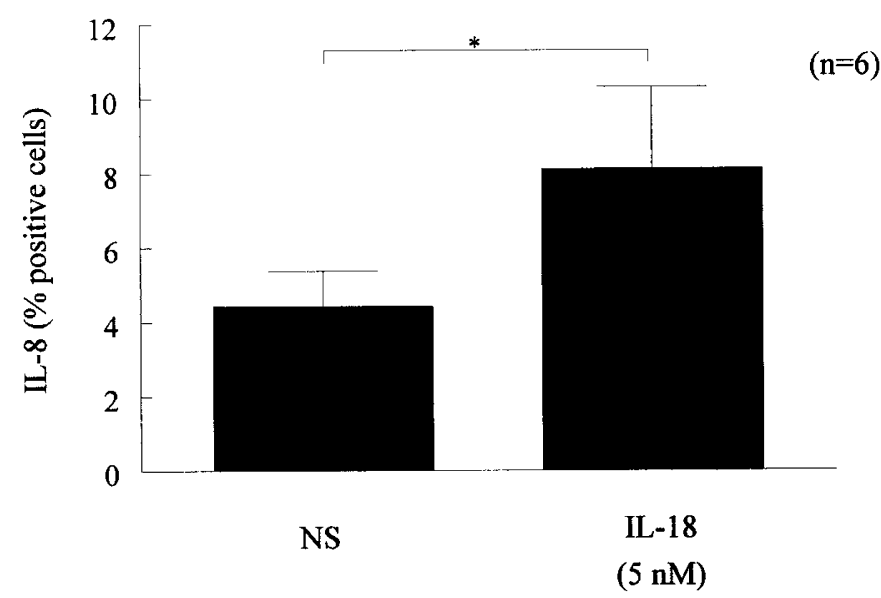

Figure 1.

Effect of interleukin (IL)-18 on endogenous IL-8 expression in rheumatoid arthritis (RA) synovial fibroblasts. A, RA synovial fibroblasts $\left(1 \times 10^{5} / \mathrm{ml}\right)$ from six different patients with RA were stimulated with IL-18, IL-1 $\beta$, or tumor necrosis factor- $\alpha$ (TNF- $\alpha$ ). After 24 hours, cells were harvested for intracellular flow cytometric analysis. The histogram is a representative intracellular experiment: $x$ axis, number of cells; $y$ axis, fluorescence intensity. Left panel, no stimulation (NS). Right panel, IL-18 stimulation: the second peak corresponds to the cells positive for IL-8. Isotype-matched control staining was less than $2 \%$. B, IL-18 stimulates IL- 8 production by intracellular FACS. Results represent the percentage \pm SEM of positively stained cells for IL-8 from two different experiments; $p<0.05$ compared with nonstimulated cells; Wilcoxon rank order test. 
fibroblasts incubated with media alone, and the right panel to the IL-18-stimulated cells. IL-18 treatment for 24 hours resulted in a 2 -fold increase in intracellular IL-8 level compared with RA synovial fibroblasts cultured with medium only (Fig. 1B). IL-1B and TNF- $\alpha$ stimulation also enhanced intracellular IL-8 by 5 - and 6-fold, respectively (data not shown). These results were confirmed by Western blot analysis (Fig. 2). This blot showed a concentration- and time-dependent increase in IL-8 expression in response to IL-18 stimulation. Compared with nonstimulated cells, 5 and 50 nM of IL-18 induced a 3- and 5.9-fold increase in IL-8 expression at 28 hours and a 13.2- and 14.7-fold increase at 96 hours.

Effect of IL-18 on Extracellular IL-8, ENA-78, grod, and MIP-1a Production by RA Synovial Fibroblasts

Next, we determined the effect of IL-18 on extracellular IL-8 production and also on the production of other CXC chemokines, such as epithelial-neutrophil activating protein (ENA-78) and growth-regulated oncogene $(\operatorname{gro} \alpha)$, and the CC chemokine macrophage inflammatory protein (MIP)- $1 \alpha$. We measured the protein levels of these chemokines in the conditioned media of fibroblasts stimulated for 24 hours with different concentrations of IL-18 using ELISA assays. The mean \pm SE values for IL-8, ENA-78, gro $\alpha$, and MIP- $1 \alpha$ are presented in Figure $3 \mathrm{~A}$ and Figure $4, \mathrm{~A}$ to C. In the absence of costimuli, IL-18 up-regulated the synthesis of the three CXC chemokines (IL-8, ENA-78, and $\operatorname{gro} \alpha$ ) in a dose-dependent manner. At $2.5 \mathrm{~nm}$, IL-18 significantly enhanced the production of IL-8, ENA-78, and gro $\alpha$ in the nanomolar range. The optimum induction was observed at a concentration of 10 nM of IL-18 with a $150 \%$ increase in IL-8, a $200 \%$ increase in ENA-78, and a $12 \%$ increase in gro $\alpha$ compared with unstimulated RA synovial fibroblasts $p$
$<0.05 ; n=5)$. Cells stimulated with IL- $1 \beta$ or TNF- $\alpha$ produced larger amounts of IL-8 (9 to $11 \mathrm{ng} / \mathrm{ml}$ ) and equal amounts of ENA-78 and gro $\alpha$ compared with those stimulated with IL-18 (data not shown). The CC chemokine MIP- $1 \alpha$ was detected in the conditioned media of RA synovial fibroblasts exposed to TNF- $\alpha$ but not in those fibroblasts exposed to IL-18 or IL-1 $\beta$.

IL-8 was used as an example to examine the time course of chemokine secretion from IL-18-stimulated RA synovial fibroblasts (Fig. 3B). Cells from five patients with RA were cultured in the presence or absence of IL-18 (5 nM), and conditioned media were collected at 4, 8, 24, and 48 hours. Nonstimulated cells released small quantities of IL-8 (between 42 $\mathrm{pg} / \mathrm{ml} \pm 0$ and $842 \mathrm{pg} / \mathrm{ml} \pm 0.6)$. In contrast, IL-18stimulated IL-8 production increased exponentially. At 4 hours, the mean IL-8 concentration was $132 \mathrm{pg} / \mathrm{ml} \pm$ 0.05 and reached $3.6 \mathrm{ng} / \mathrm{ml} \pm 1.2$ at 48 hours.

\section{IL-18 Does Not Synergize with IL-12 to Induce IL-8}

IL-12 is another proinflammatory and immunomodulatory cytokine that has a central role in directing the $\mathrm{Th}_{1}$ response (Hsieh et al, 1993; Seder et al, 1993). One of the characteristics of IL-12 is its synergistic function with IL-18, in vitro (Yoshimoto et al, 1997, 1998) and in vivo (Leung et al, 2000; Zhang et al, 1997). We therefore studied a combination of IL-12 and IL-18 for the ability to stimulate RA synovial fibroblast IL-8 production. IL-12 alone, at 70, 280, and 1400 pм stimulated little IL-8 expression. Using 70 pм of IL-12 and increasing concentrations of IL-18, there was no augmented induction of IL-8 production (Fig. $5 A)$. The repetition of this experiment with a higher concentration of IL-18 (5 nM) and three different concentrations of IL-12 (70 pM, 280 pM, and 1400 pm) induced similar levels of IL-8, compared with levels of IL-8 induced by IL-18 alone (Fig. 5B), confirming the

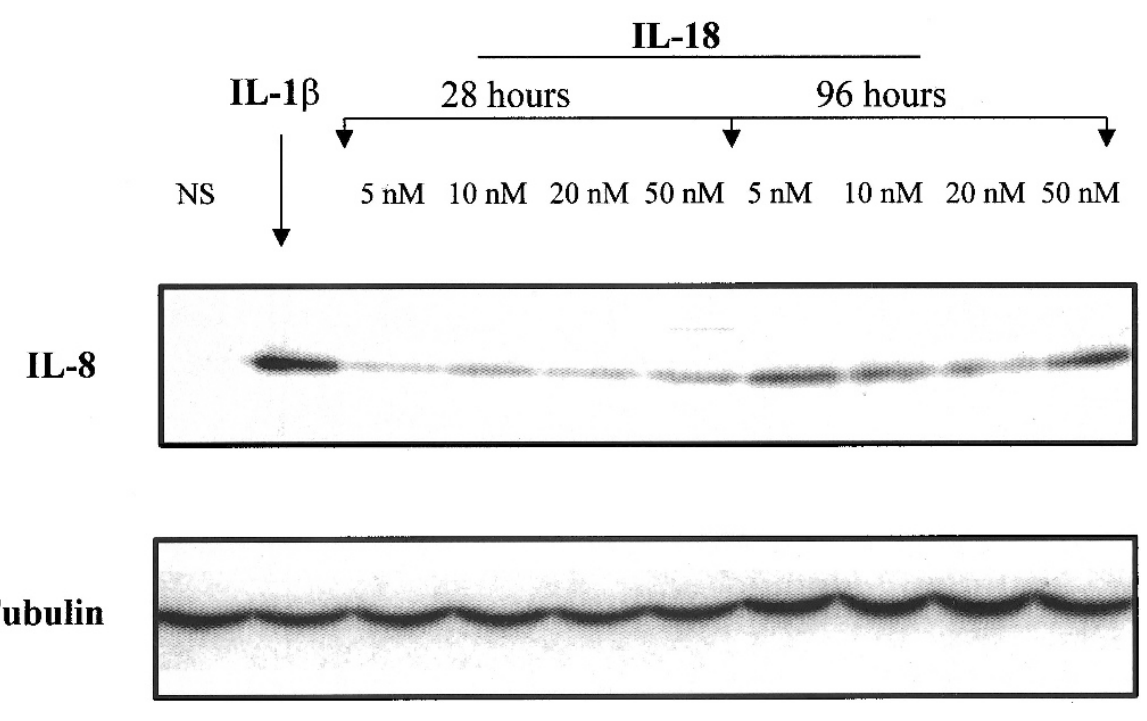

Figure 2.

Time course and dose response of endogenous IL-8 expression by Western blot. RA synovial fibroblasts $\left(1 \times 10^{5} / \mathrm{ml}\right)$ were stimulated with IL-1 $\beta$ or various concentrations of IL-18 for 28 hours and 96 hours. Equal amounts of extracted proteins were separated by SDS gel electrophoresis, and Western blotting was performed as described in "Materials and Methods." Equal loading of protein was verified with anti-tubulin antibody. 
$\mathbf{A}$

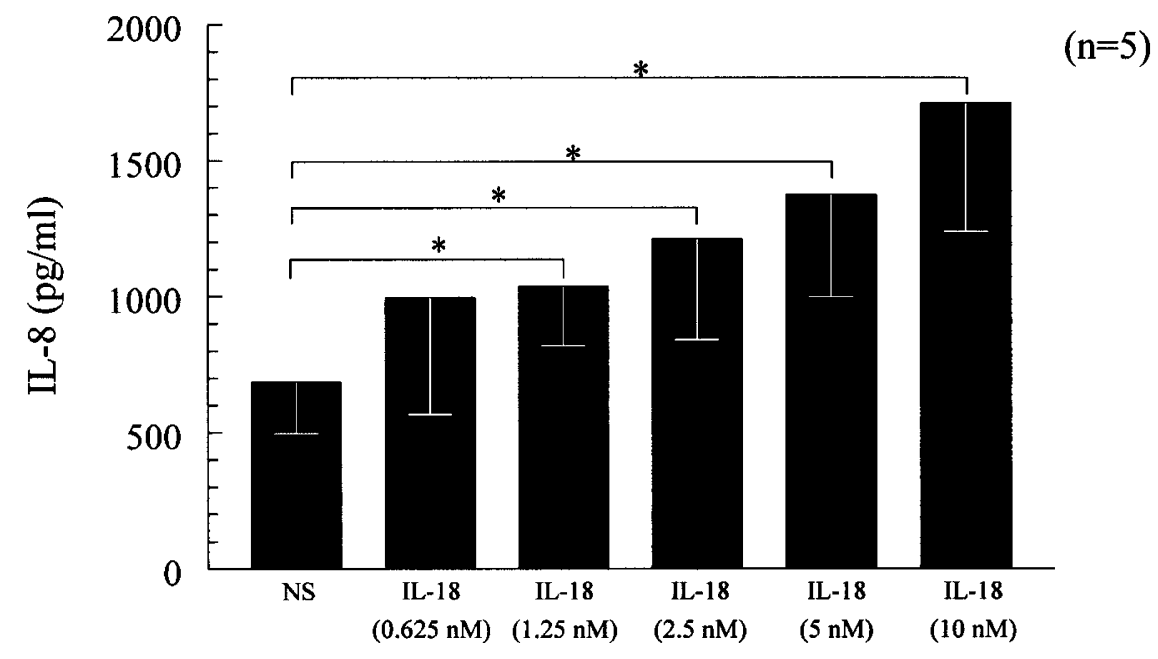

B

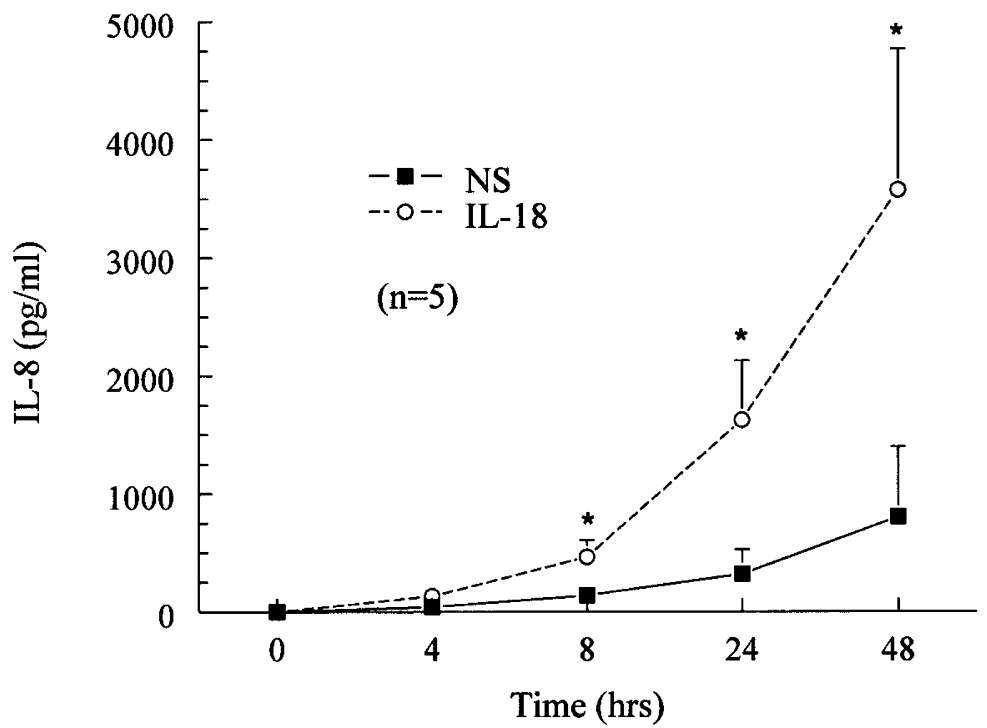

Figure 3.

Time- and dose-dependent production of IL-8 by IL-18-stimulated RA synovial fibroblasts. A, Equal numbers of cells $\left(1 \times 10^{5} / \mathrm{ml}\right)$ were stimulated with various concentrations of IL-18 indicated on the horizontal axis. Conditioned media were collected after 24 hours and assayed for IL-8 by ELISA. B, For the time-dependent generation of IL-8, RA synovial fibroblasts $\left(1 \times 10^{5} / \mathrm{ml}\right)$ were cultured for various time points in the presence or absence of $5 \mathrm{~nm} \mathrm{IL-18}$. Results represents the means \pm SEM of conditioned media from five different patients with RA. ${ }^{*} p<0.05$ compared with nonstimulated control; Student $t$ test.

absence of a synergistic effect of these two cytokines in combination on RA synovial fibroblasts.

\section{IL-18 Induces Nuclear Translocation of NFKB (p65) in RA Synovial Fibroblasts}

Next, we investigated the intracellular pathway used by IL-18 to induce chemokine production. Because IL-18 was reported to induce NF $\kappa$ B activation (Matsumoto et al, 1997; Shapiro et al, 1998; Torigoe et al, 1997), we investigated whether this transcription factor was involved in the IL-18-induced IL-8 expression. When $\mathrm{NF}_{\kappa} \mathrm{B}$ is activated, it translocates from the cytoplasm to the nucleus. To assess the nuclear translocation of $N F_{\kappa} B$ in $\mathrm{RA}$ synovial fibroblasts, we subjected cytoplasmic and nuclear extracts from control and IL-18-induced cells to Western blot analysis (Fig. 6). In the cytoplasm of cells stimulated with IL-18 for 0.5 and 1 hour, the amount of $\mathrm{NF} \kappa \mathrm{B}$ p65 was higher compared with control nonstimulated cells. Incubation with IL-18 resulted in an increase in the nuclear expression of p65 that occurred at 2 hours and was sustained for at least 4 hours. This translocation of $\mathrm{NF} \kappa \mathrm{B}$ p65 to the nucleus is illustrated in Figure 7 using immunofluorescence (arrows). RA synovial fibroblasts treated with IL-18 $(5 \mathrm{nM})$ or IL-1 $\beta$ $(1.75 \mathrm{~nm})$ for 1 hour induced a nuclear uptake of p65 as demonstrated by nuclear staining (arrows) (Fig. 7, B 
$\mathbf{A}$

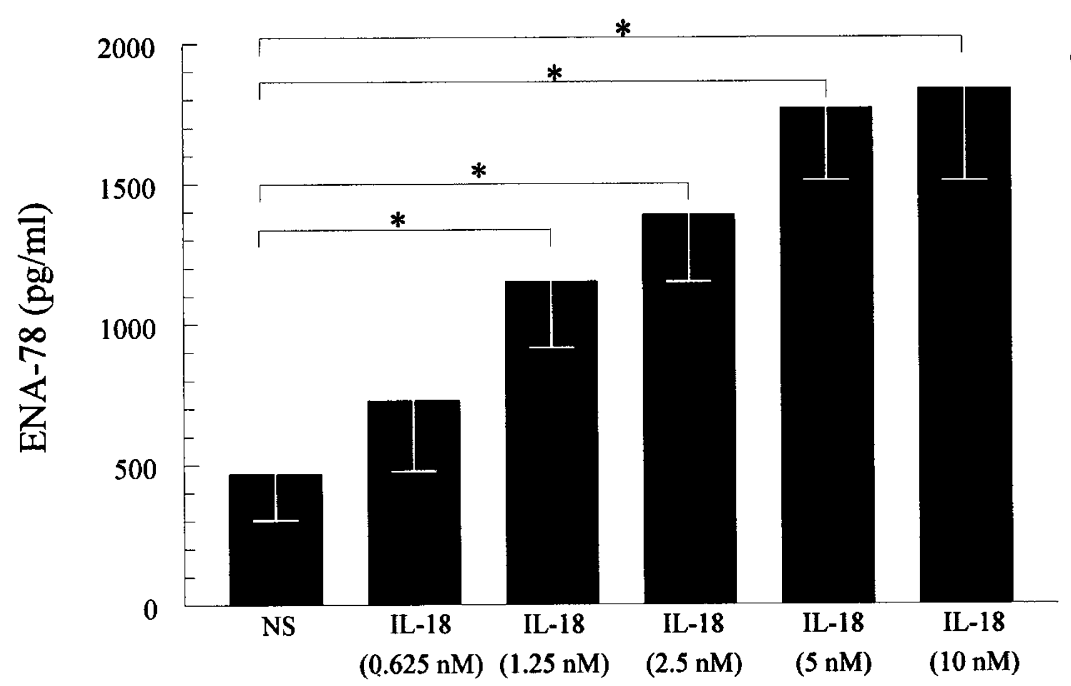

$(n=5)$

$(n=5)$

B

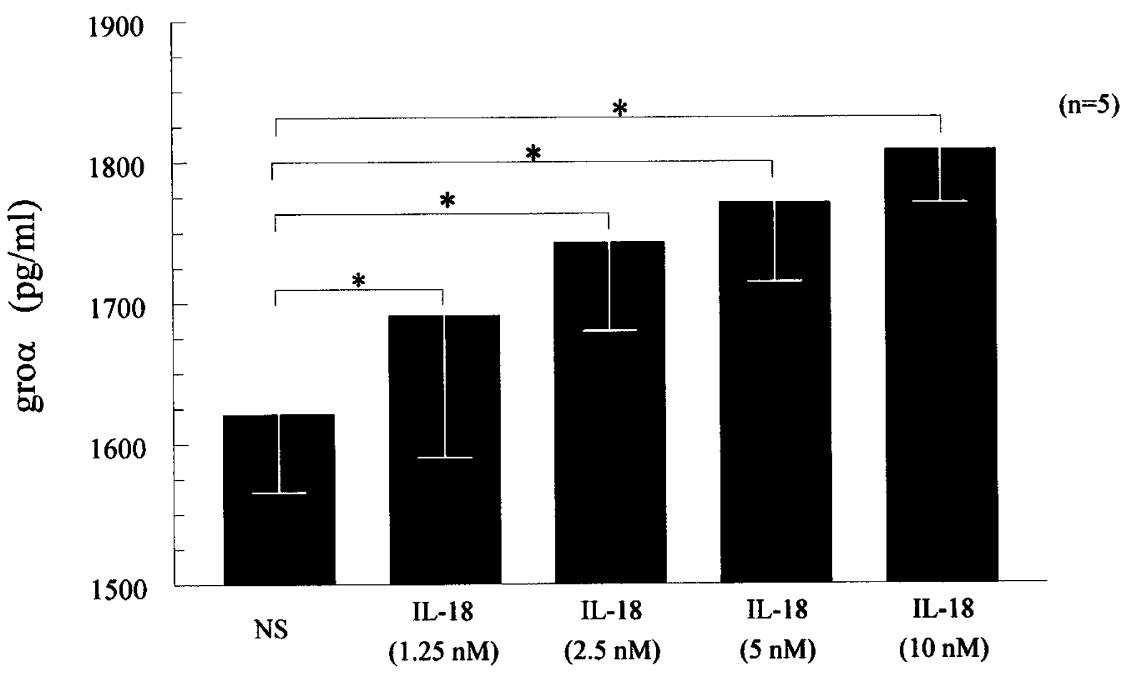

C

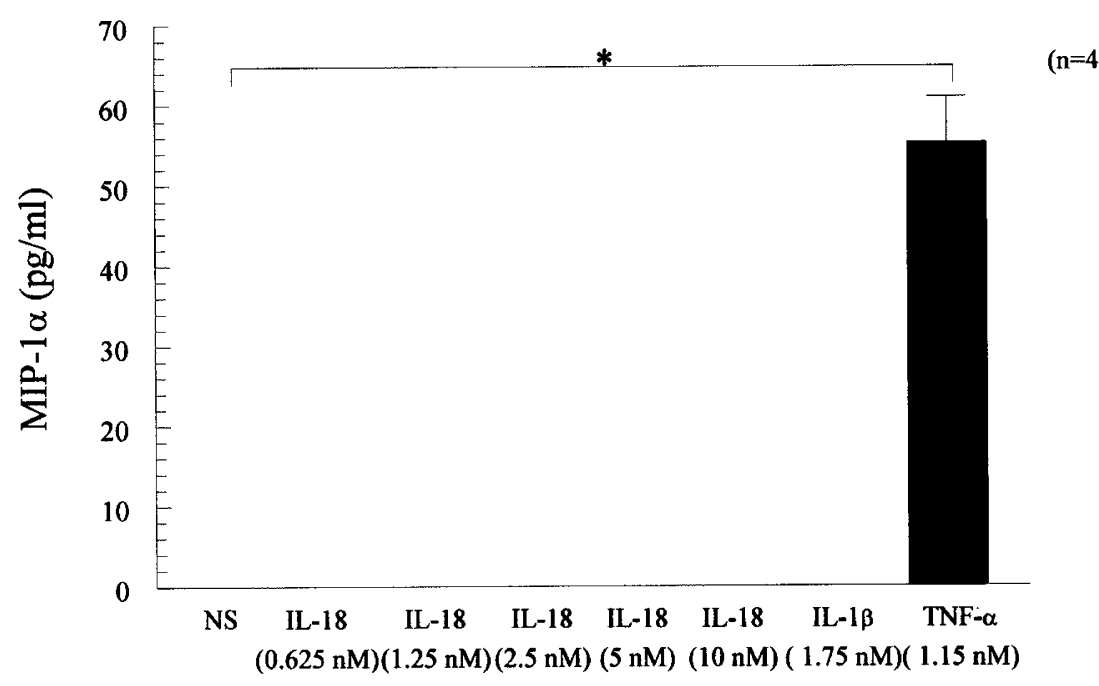

Figure 4.

Epithelial-neutrophil activating protein (ENA-78) (A), growth-regulated oncogene (gro $\alpha)(B)$, and macrophage inflammatory protein (MIP)-1 $\alpha$ (C) production by RA synovial fibroblasts treated with IL-18. The procedure used to collect conditioned media for these experiments is described in Figure 3 . Chemokines released in the conditioned media were measured by ELISA. Results represent the mean \pm SEM of cells from five different patients with RA. ${ }^{*} p<0.05$ compared with nonstimulated control using a Student $t$ test. 
A

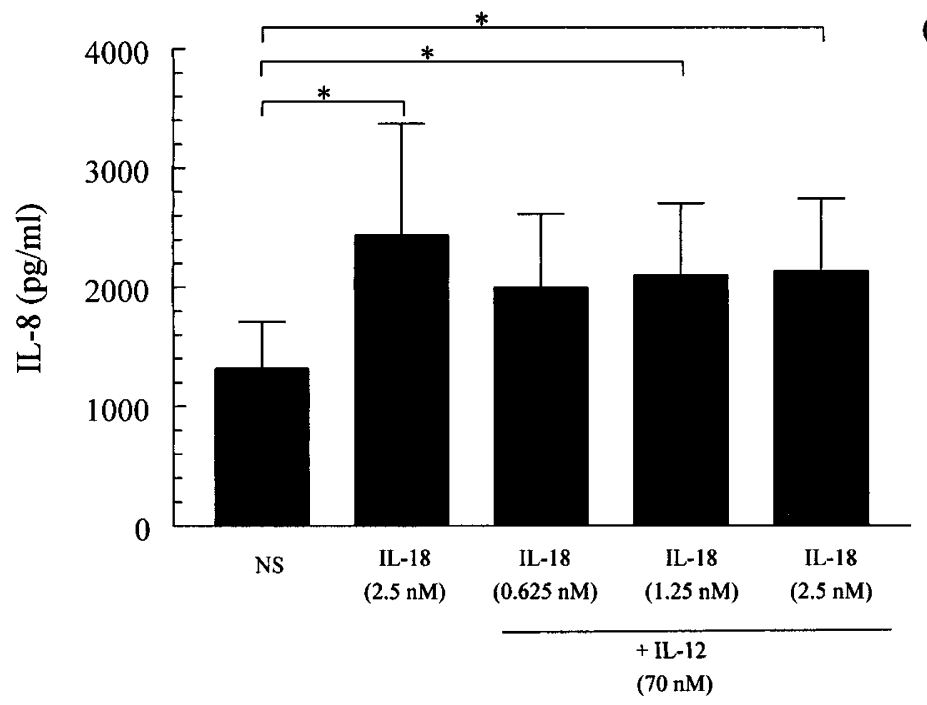

$(n=4)$

B

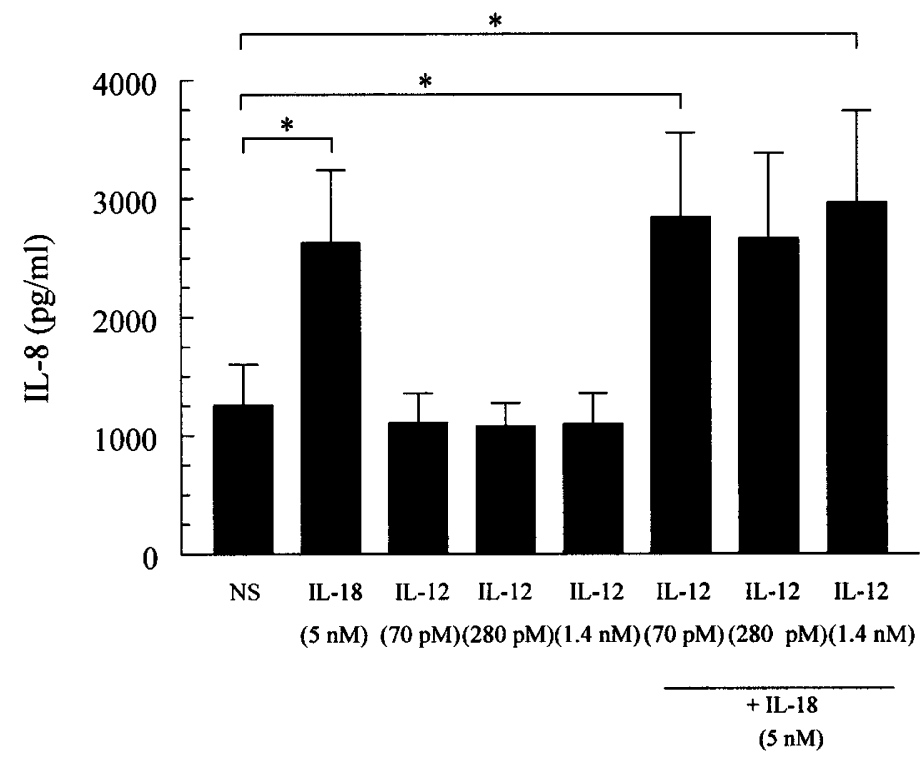

Figure 5.

IL-8 expression in response to combinations of IL-18 and IL-12 in RA synovial fibroblasts. Cells were cultured as described in Figure 1 and stimulated (A) with various concentrations of IL-18 plus IL-12 (70 pM) or (B) various concentrations of IL-12 plus IL-18 or IL-12 alone. Conditioned media was collected after 24 hours and assayed by ELISA. Results represent the mean \pm SEM of cells from three (B) and four (A) different patients with RA. ${ }^{*} p<0.05$ compared with nonstimulated control using a Student $t$ test.

and $\mathrm{C}$ ), as opposed to the cytoplasmic distribution in unstimulated cells (Fig. 7A).

\section{Effect of NFKB Antisense on IL-18-Induced RA Synovial Fibroblasts IL-8}

The above findings showed that $\mathrm{NF} \kappa \mathrm{B}$ activation occurred after IL-18 stimulation. To link this activation of $\mathrm{NF} \kappa \mathrm{B}$ with IL-8 expression, we examined the effect of $\mathrm{NF} \kappa \mathrm{B}$ inhibition on IL-18-induced IL-8 production. In previous reports, antisense has been successfully used to modulate $\mathrm{NF} \kappa \mathrm{B}$ to assess its role in IL-8 expression (Roshak et al, 1996). We tested the effect of the antisense oligonucleotide on $\mathrm{NF} \kappa \mathrm{B}$ p65 synthesis in IL-18- and IL-1 $\beta$-stimulated RA synovial fibroblasts by Western Blotting. In the presence of antisense oligonucleotide, the amount of p65 in IL-18and IL-1 $\beta$-stimulated cells was similar to the amount in nonstimulated cells. RA synovial fibroblasts in RPMI-1640 supplemented with $10 \%$ fetal bovine serum (FBS) and 1\% penicillin/streptomycin (P/S) were incubated with sense or antisense oligonucleotides $(10 \mu \mathrm{M})$ for 18 hours at $37^{\circ} \mathrm{C}$ before the addition of $\mathrm{IL}-18$ for 24 hours. Protein extracts were collected and assayed for Western blot analysis (Fig. 8A). Figure 8B 
A
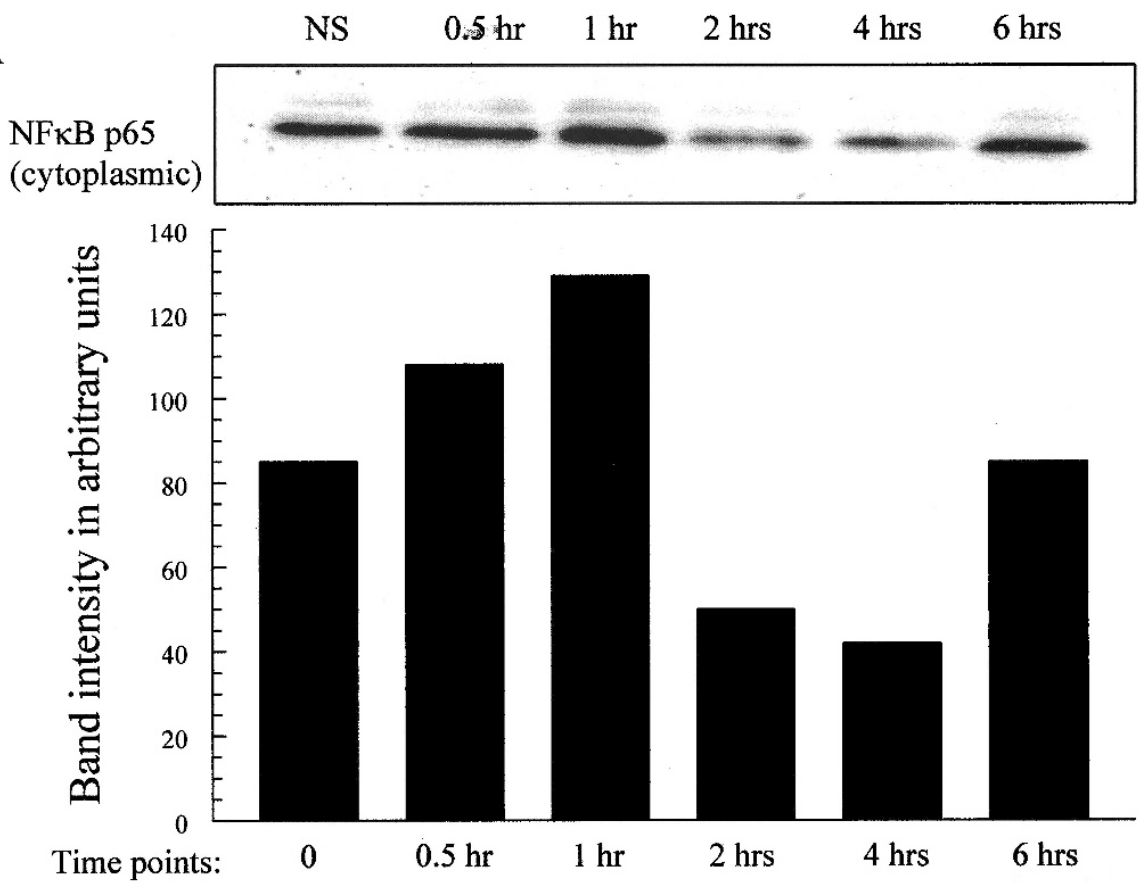

IL-18 (5nM)

B

NS $\quad 0.5 \mathrm{hr} \quad 1 \mathrm{hr} \quad 2 \mathrm{hrs} \quad 4 \mathrm{hrs} \quad 6 \mathrm{hrs}$

NFkB p65

(nuclear)
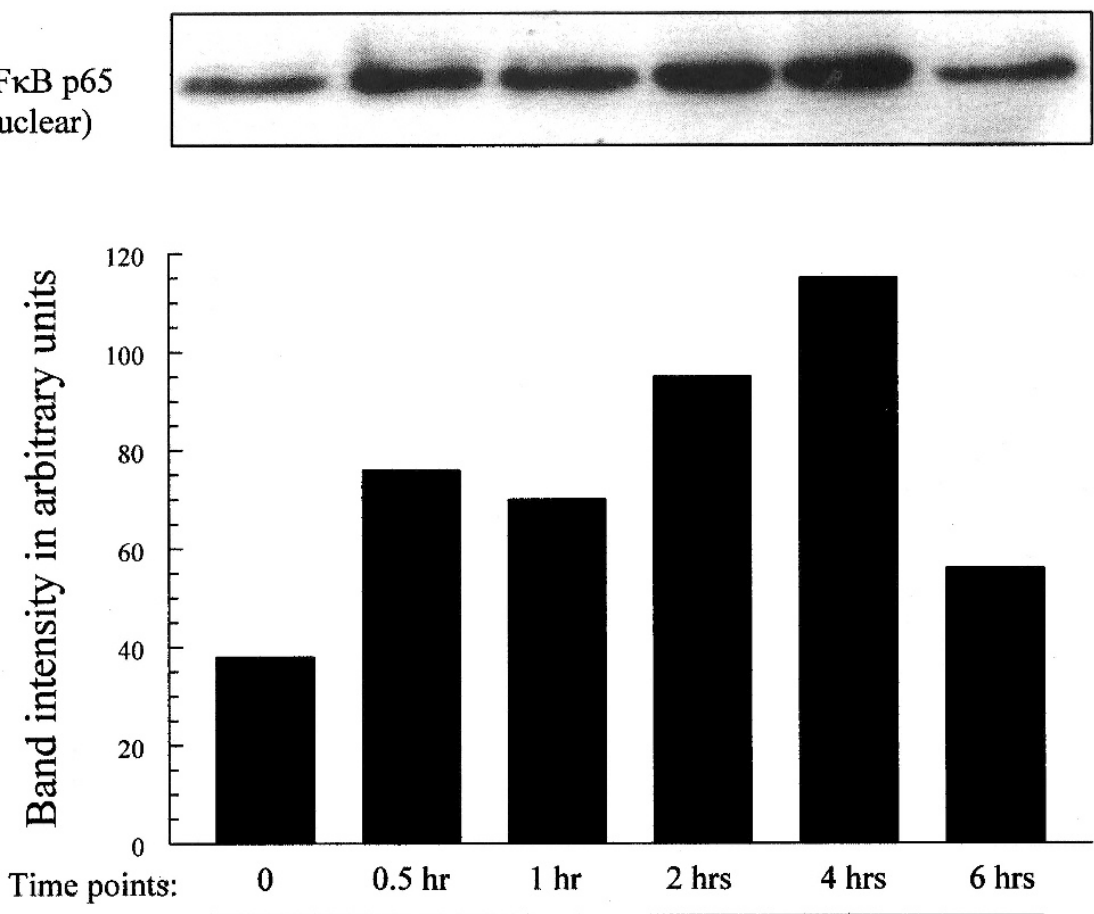

IL-18 (5nM)

Figure 6.

Disappearance of nuclear factor kappa $\mathrm{B}(\mathrm{NF} \kappa \mathrm{B})$ in the cytoplasm and appearance in the nucleus induced by IL-18. Western blot analysis of NF $\mathrm{B}$ (p65) was performed with cytoplasmic and nuclear extracts from RA synovial fibroblasts from three different patients with RA, after stimulation with IL-18 (5 nM) for 0 to 6 hours. An $8.5-\mu \mathrm{g}$ protein extract of each sample was loaded. The graph represents the band intensities in pixel values for each condition. Results are representative of three experiments.

shows that IL-8 levels of IL-18- and IL- $1 \beta$-stimulated RA synovial fibroblasts, pretreated with $10 \mu \mathrm{M}$ p65 antisense, were significantly $(p<0.05)$ reduced by
$-44 \%( \pm 5.4)$ and $-46 \%( \pm 13.32)$, respectively. These results indicated that $\mathrm{NF} \kappa \mathrm{B}$ activation in part modulated IL-18-induced RA synovial fibroblast IL-8 expression. 

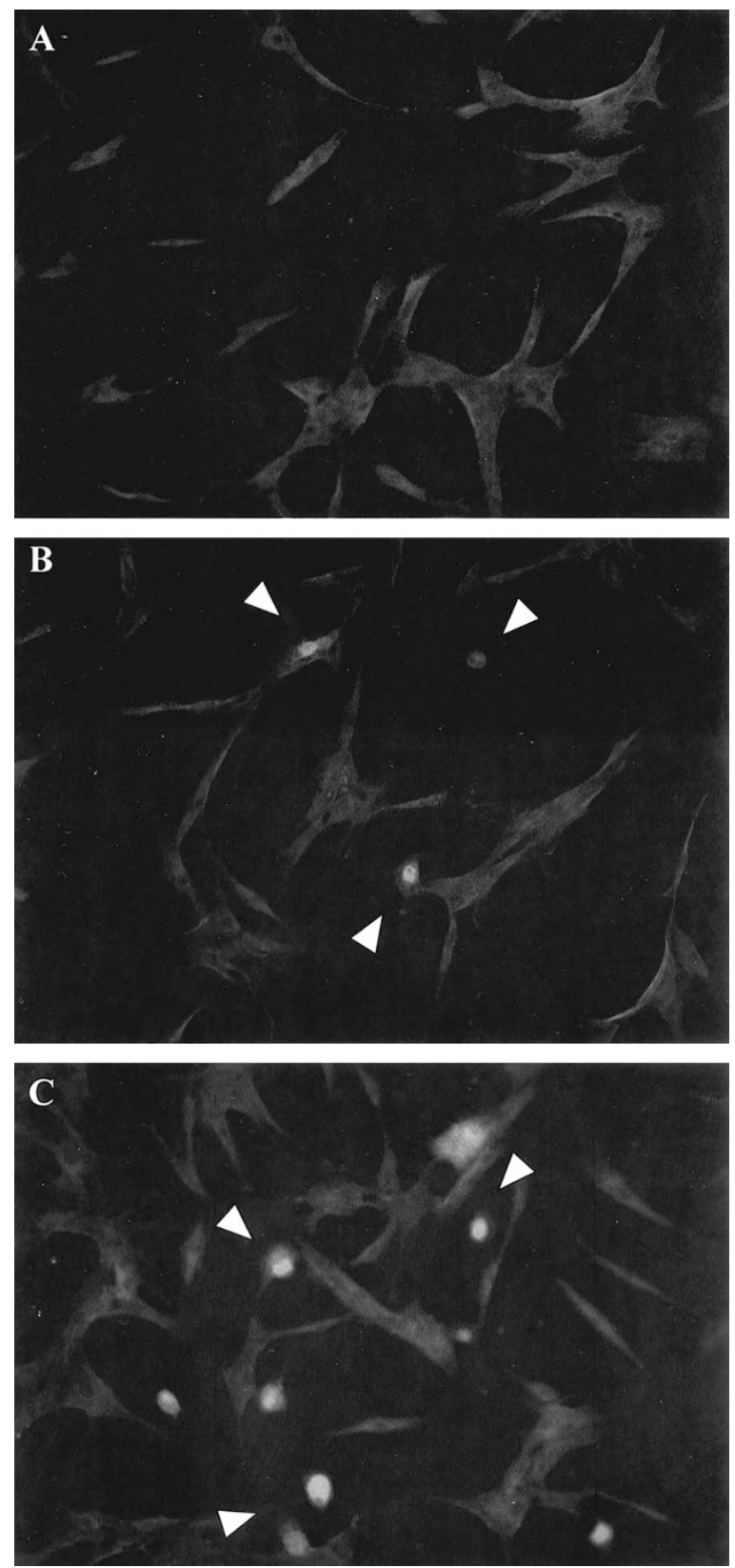

Figure 7.

Nuclear translocation of $\mathrm{NF}_{\kappa} \mathrm{B}$ upon IL-18-stimulation of RA synovial fibroblasts. Cells from two different patients with RA were stimulated by (A) media alone, (B) IL-18 (5 nM), or (C) IL-1 $\beta$ (1.75 nM) for 1 hour. The bound antibody was visualized with FITC-conjugated goat anti-rabbit $\operatorname{lgG}$ (green). Cells stimulated with IL-18 or IL-1 $\beta$ demonstrated accumulation of $\mathrm{NF} \kappa \mathrm{B}$ (p65) in the nucleus, whereas nonstimulated cells did not. A to $\mathrm{C}, \times 469$. Arrows indicate the $\mathrm{NF}_{\kappa} \mathrm{B}$ p65 located in the nucleus.

\section{Discussion}

In this study, we demonstrated that IL-18 stimulates RA synovial fibroblasts to produce CXC chemokines. $\mathrm{IL}-18$, in the absence of an IL-12 costimulus induced a dose-dependent increase in the amount of IL-8, ENA78 , and gro $\alpha$ but failed to induce MIP- $1 \alpha$ production even at the highest concentrations employed. These biological actions of IL-18 on synovial fibroblasts appear similar to IL-1 $\beta$ functions, because, in our hands, IL-1 $\beta$ did not induce RA synovial fibroblast
MIP-1 $\alpha$ production (Koch et al, 1994). Previous studies showed that normal peripheral blood CD14+ monocytes and natural killer (NK) cells released IL-8 and MCP-1 upon exposure to IL-18 (Puren et al, 1998), whereas MIP-1 $\alpha$ was undetectable at the mRNA and protein levels in IL-18 activated NK cells (Fehniger et al, 1999). In the U1 monocytic cell, IL-18 up-regulated IL-8 but had no effect on MIP-1 $\alpha$ (Shapiro et al, 1998). In both cases the addition of the p55 TNF soluble receptor (TNFbp), which inhibits TNF- $\alpha$ functions, reduced the IL-18-induced IL-8 production, and the authors concluded that IL-18 exerted its effect through a TNF- $\alpha$-like molecule. However, IL-8 was not completely inhibited by TNFbp, suggesting that another factor enhanced IL-8 gene expression. Actually, a direct effect of IL-18 in IL-8 production is a reasonable explanation, and the early detection ( 4 and 8 hours) of IL- 8 in the conditioned media, as well as in the cytoplasm of RA synovial fibroblasts stimulated with IL-18, strongly supports this hypothesis. Moreover, synovial fibroblasts do not produce TNF- $\alpha$ (Bombara et al, 1993; Bucala et al, 1991; Schwachula et al, 1994), even when they are stimulated with lipopolysaccharide (LPS), suggesting that the production of IL-8 by RA synovial fibroblasts is probably linked to a direct effect of IL-18 on these cells. MIP- $1 \alpha$ is chemotactic for monocytes, whereas ENA-78, gro $\alpha$, and IL-8 are important in neutrophil recruitment in the RA joint (Koch and Strieter, 1996). The participation of IL-18 in the recruitment of neutrophils has been demonstrated in vivo. In a lethal endotoxemia model, mice injected with LPS derived from Escherichia coli die of vital organ injury, which is largely mediated through neutrophil accumulation (Netea et al, 2000). The neutralization of IL-18 significantly reduced neutrophil infiltration in the lung and the liver and also the expression of the chemokine MIP-2 in these organs. These observations suggest that IL-18 inhibition may result in decreased neutrophil recruitment through inhibition of chemokine production. It is conceivable that IL-18, produced by $R A$ synovial fibroblasts, could promote neutrophil trafficking into the joint via chemokine induction and participate in the inflammation of the joint. This could, in part, explain the development in mice treated with type II collagen and IL-18 of a more inflammatory and erosive arthritis than that which developed in the control animals (Leung et al, 2000).

Because IL-12 was shown to synergize with IL-18 to induce chemokines in normal peripheral blood mononuclear cells (PBMC) (Puren et al, 1998), we examined the combination of these two cytokines on RA synovial fibroblast IL-8 expression. Surprisingly, there was no additive effect of IL-12 on IL-8 production because the levels of IL- 8 released by the cells treated with IL-12 alone were identical with those treated with IL-12 combined with IL-18. This result was unexpected because IL-12 increased IL-18-induced chemokine expression in NK cells. The up-regulation of IL-18 receptor by IL-12 is one mechanism that explains the synergistic effect of these two cytokines. However, IL-12 alone appears 
$\mathbf{A}$ sense NFkB p65 antisense NFkB p65
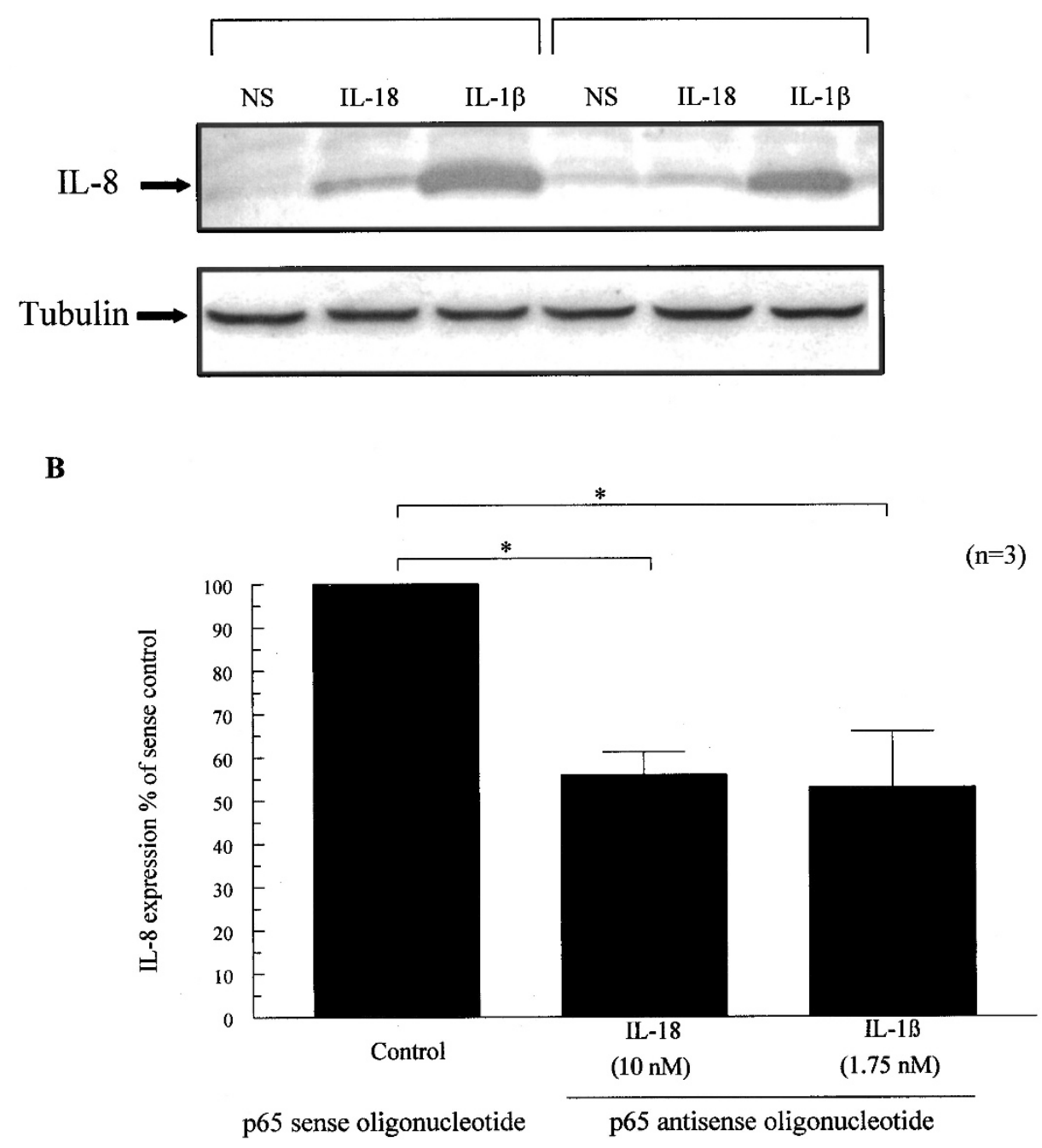

Figure 8.

The effect of antisense to $\mathrm{NF}_{\kappa} \mathrm{B}$ p65 on RA synovial fibroblast IL-8 protein levels. A, Western blot analysis of $32 \mu \mathrm{g}$ of protein extracted from RA synovial fibroblasts exposed to p65 sense or p65 antisense oligonucleotide $(10 \mu \mathrm{m})$ for 18 hours followed by treatment with IL-18 (10 nM) or IL-1 $\beta$ (1.75 nM) for 24 hours. Equal loading of protein was verified with anti-tubulin antibody. B, Data are expressed as the percentage of stimulated control oligonucleotide (sense p65) and represent mean \pm SEM of three different experiments. *Indicates significant differences from IL-18 and IL-1 $\beta$ control at $p<0.05$ using a Student $t$ test.

to have no impact on the induction of RA synovial fibroblast chemokine production (Schlaak et al, 1995; Seitz et al, 1996). Therefore, it is possible, though not described to date, that RA synovial fibroblasts lack the IL-12 receptor, explaining the absence of costimulation with IL-18.

We sought to understand the mechanism of action of $\mathrm{IL}-18$ in inducing chemokine expression in RA synovial fibroblasts. The transcription factor $N F \kappa B$ regulates many genes for inflammatory mediators, including IL-8. NF $\kappa \mathrm{B}$ is a homo- or heterodimeric protein typically containing the $\mathrm{p} 50$ and $\mathrm{p} 65$ subunits, which can bind to short regulatory sequences in the promoter sections of genes (Zhu et al, 1997). In RA synovial fibroblasts, $\mathrm{NF}_{\kappa} \mathrm{B}$ normally resides in the cytoplasm and migrates to the nucleus when it is activated. Evidence has accumulated that the intracellular pathway involving the transcription factor $N F \kappa B$ also has a role in mediating IL-18 functions (Dinarello, 1999). Kurimoto and colleagues showed that IL-18 activates $\mathrm{NF} \kappa \mathrm{B}$ in murine $\mathrm{Th}_{1}$ lymphocytes and in KG1 cells (Kojima et al, 1999; Matsumoto et al, 1997). Here, we demonstrated that IL-18 increases the translocation of $\mathrm{NF} \kappa \mathrm{B}$ p 65 to the nucleus in synovial fibroblasts derived from patients with RA. This translocation occurred at 1 hour, as demonstrated by immunofluorescence, and was sustained for at least 4 hours. This period of activation of $\mathrm{NF} \kappa \mathrm{B}$ is longer than that found with IL- $1 \beta$ stimulation of RA synovial fibroblasts because the level of $\mathrm{NF} \kappa \mathrm{B}$ in the nucleus and cytoplasm of IL-1 $\beta$-stimulated synovial fibroblasts reaches its maximum by 30 minutes and returns to the basal level by 4 hours (Crofford et al, 1997). However, this long duration of $\mathrm{NF} \kappa \mathrm{B}$ activation is not exceptional; thrombin, for example, induced a maximum activation of $\mathrm{NF}_{\kappa} \mathrm{B}$ in RA synovial fibroblasts at 4 hours after 
stimulation (Shin et al, 1999). These results suggest that the regulation of $\mathrm{NF} \kappa \mathrm{B}$ activation differs between $\mathrm{IL}-18$ and IL-1 $\beta$. The inability of IL-18 to induce in RA synovial fibroblasts the p38 mitogen-activated protein kinase, an enzyme which contributes to NF- $\kappa$ B activation and IL-8 production mediated through IL-1 $\beta$ (Suzuki et al, 2000), supports this hypothesis (data not shown).

To extend our results further, we have addressed the question of whether the activation of $N F_{\kappa} B$ is implicated in IL-18-induced IL-8 expression. Because previous reports indicated that $\mathrm{NF} \kappa \mathrm{B}$ p65 has a major role in IL-8 gene transcription (Kunsch and Rosen, 1993), we generated a phosphorothioate-modified antisense oligonucleotide corresponding to the $5^{\prime}$ end of the p65 mRNA and evaluated its effect on IL-8 protein expression. RA synovial fibroblasts pretreated with the antisense oligonucleotide p65 produced $44 \%$ less IL-8 compared with the cells treated with the control sense oligonucleotide. Thus, IL-8 production was partially abolished in the cells stimulated with IL-18 or IL-1 $\beta$. Roshak and colleagues (1996) also found a partial inhibition of IL- $1 \beta$-induced IL-8 expression ( $45 \%$ to $55 \%$ ) in RA synovial fibroblasts treated with a similar antisense p65 oligonucleotide. The use of antisense technology prevents only synthesis of new p65, not translocation of preformed cytoplasmic p65. Therefore, the early activation of preformed $\mathrm{NF}_{\kappa} \mathrm{B}$ could explain the partial decrease of IL-8 expression. Antisense p65 oligonucleotide also does not block the synthesis of other subunits of $N F \kappa B$, such as p50 or C-rel, which are also important in the regulation of IL-8 production (Roshak et al, 1996). These subunits might form alternative homo- or heterodimers that could compensate for the loss of p65. An NFKB-independent pathway involving other transcription factors, such as activating protein-1 (AP-1), is another possible explanation, because this factor is activated in response to IL-18 in various cell systems (Barbulescu et al, 1998; Kojima et al, 1999). To support this idea, IL- $1 \beta$ requires a NF $\kappa B$ element plus either an AP-1 or a CCAAT/enhancerbinding protein element to induce IL-8 gene transcription (Wu et al, 1997; Yasumoto et al, 1992). Further investigation is needed to elucidate the roles of these different transcription factors in RA synovial fibroblasts stimulated with IL-18.

In summary, this study demonstrates by four different techniques that IL-18 induces intracellular and extracellular expression of IL-8 by RA synovial fibroblasts, in a dose- and time-dependent manner. In the same cells, IL-18 up-regulates other chemokines such as ENA-78 and gro $\alpha$ but fails to induce MIP- $1 \alpha$. IL-18 enhances CXC chemokine production in RA synovial fibroblasts through activation of the transcription factor $\mathrm{NF}_{\kappa} \mathrm{B}$ p65, at least for IL-8. These studies support the concept of considering IL-18 as a directly acting proinflammatory cytokine in the RA joint and place this cytokine in a strategic role in inflammation and in RA.

\section{Materials and Methods}

\section{Reagents}

Cytokines. Human recombinant (rhu) IL-18 (specific activity: $9.1 \times 10^{5}$ units $/ \mathrm{mg}$ ) and rhu IL-12 (specific activity: $1.24 \times 10^{7}$ units $/ \mathrm{mg}$ ) were purchased from $R \& D$ Systems (Minneapolis, Minnesota). Rhu interleukin-1 beta (IL-1 $\beta, 2 \times 10^{7}$ units/mg) and rhu tumor necrosis factor- $\alpha$ (TNF- $\alpha$, specific activity: $1.3 \times 10^{7}$ units $/ \mathrm{mg}$ ) were obtained from Upjohn Company (Kalamazoo, Michigan).

Antibodies. Monoclonal mouse anti-human IL-8 and isotype-matched antibodies were purchased from R\&D Systems. Polyclonal rabbit anti-RelA was acquired from Santa Cruz Biotechnology (Santa Cruz, California). FITC-conjugated goat anti-rabbit antibody was purchased from Jackson ImmunoResearch (West Grove, Pennsylvania). Monoclonal mouse anti-tubulin was purchased from Oncogene (Boston, Massachusetts). Monensin (Golgistop7) was purchased from Pharmingen (San Diego, California). Goat serum was obtained from Sigma (St. Louis, Missouri). RPMI-1640, PBS, fetal bovine serum (FBS), and penicillin/streptomycin (P/S) were from Gibco BRL (Grand Island, New York).

\section{Fibroblast Cell Culture}

Synovium was obtained from patients meeting the American College of Rheumatology criteria for RA who had undergone total knee replacement surgery or synovectomy. Fresh synovial tissues were minced and digested in a solution of dispase, collagenase, and DNAse. Synovial fibroblasts were cultured at $37^{\circ} \mathrm{C}$ in RPMI-1640 supplemented with 10\% FBS and 1\% P/S in 175-mm tissue culture flasks (Falcon, Franklin Lakes, New Jersey). Upon reaching confluence, the cells were passaged by brief trypsinization as previously described (Koch et al, 1986). The cells were used at passage 5 or older, at which time they were a homogeneous population of fibroblasts. To obtain conditioned media, synovial fibroblasts were seeded at $1 \times 10^{6} \mathrm{cells} / \mathrm{ml}$ in 24-well plates (Falcon) in $1 \mathrm{ml}$ supplemented RPMI-1640 and incubated overnight at $37^{\circ} \mathrm{C}$ in an incubator gassed with $5 \% \mathrm{CO}_{2}$. Different concentrations of IL-18 (0.625 nM to $10 \mathrm{nM}), \mathrm{IL}-1 \beta$ (1.75 nm), TNF- $\alpha$ (1.15 nM) in RPMI-1640 with $1 \% \mathrm{P} / \mathrm{S}$ were added to the plates, and the plates were incubated at $37^{\circ} \mathrm{C} / 5 \% \mathrm{CO}_{2}$. Conditioned media was collected after $4,8,24$, and 48 hours of culture and stored at $-80^{\circ} \mathrm{C}$ until assayed.

\section{Chemokine ELISA}

IL-8, gro $\alpha$, ENA-78, and MIP- $1 \alpha$ in the cell cultureconditioned media were assayed using commercial ELISA assays (R\&D Systems). The sensitivity of these assays ranged from 10 to $15 \mathrm{pg} / \mathrm{ml}$.

\section{Intracellular Flow Cytometry}

Synovial fibroblasts were cultured in RPMI-1640 at 1 $\times 10^{6} \mathrm{cells} / \mathrm{ml}$ in 6 -well plates and stimulated with 
IL-18 (5 nM), IL-1 $\beta$ (1.75 nM), or TNF- $\alpha$ (1.15 nм) for 24 hours. Conditioned media were then collected, and synovial fibroblasts were restimulated with the same concentration of cytokines but in the presence of monensin $(1.3 \mu \mathrm{l}$ for $2 \mathrm{ml}$ of media) for 4 hours. Cells were harvested with a cell scraper and transferred to fluorescence activated cell sorting (FACS) tubes (Becton Dickinson, Franklin Lakes, New Jersey). Synovial fibroblasts were then stained for intracellular IL-8 according to Becton Dickinson protocol. Briefly, the synovial fibroblasts were lysed and permeabilized with Becton Dickinson lysing and permeabilization solutions before they were incubated successively for 30 minutes at room temperature with a monoclonal antiIL-8 antibody or isotype-matched control $(2.5 \mu \mathrm{g} / \mathrm{ml})$ and phycoerythrin $(\mathrm{PE})$-conjugated goat anti-mouse antibody (50 $\mu \mathrm{l}$ of 1:100 dilution). Samples fixed in 1\% paraformaldehyde were assayed using an Epics XLMCL flow cytometer (Beckman Coulter, Fullerton, California). Before data acquisition, the PE channel was standardized using fluorescent beads (Rainbow Beads; Spherotech, Libertyville, Illinois).

\section{Immunofluorescence Staining}

To determine the subcellular localization of $\mathrm{NF}_{\kappa} \mathrm{B}, \mathrm{RA}$ synovial fibroblasts were cultured at 10,000 cells/well in eight-well Lab-Tek (Naperville, Illinois) chamber slides and allowed to adhere overnight. Cells were then stimulated with $5 \mathrm{~nm} \mathrm{IL-18}$ or $1.75 \mathrm{nM}$ IL- $1 \beta$ for 1 hour. RA synovial fibroblasts were fixed in PBS containing $4 \%$ paraformaldehyde for 10 minutes at room temperature and then permeabilized using $0.5 \%$ Triton X-100 in PBS for 20 minutes at room temperature. They were then incubated with rabbit polyclonal antiRel-A antibody or an isotype-matched control for 45 minutes at $37^{\circ} \mathrm{C}$. After washing with PBS, cells were incubated with FITC-conjugated goat anti-rabbit antibody for 45 minutes at $37^{\circ} \mathrm{C}$. Slides were coverslipped with mounting media (Kirkegaard \& Perry Labs, Gaithersburg, Maryland). Subcellular localization was determined using an immunofluorescence microscope.

\section{Preparation of Phosphorothioate Oligonucleotides}

Initiation site-directed antisense to p65, 5'ggggaacagttcgtccatggc- $3^{\prime}$, and control oligonucleotide p65 sense, 5'-gccatggacgaactgttcccc-3', were synthesized on a 394 DNA/RNA synthesizer from Applied Biosystems (Foster City, California) using phosphoroamidite chemistry. Sense and antisense oligonucleotides were resuspended in RPMI-1640, $10 \% \mathrm{FBS}$, and $1 \% \mathrm{P} / \mathrm{S}$. RA synovial fibroblasts were cultured in the presence of sense or antisense p65 (10 $\mu \mathrm{M})$ for 18 hours before the addition of IL-18 (10 nM) for 24 hours. Monensin was added 4 hours before the protein extraction.

\section{Nuclear Extracts}

Cells were scraped, washed once with PBS, resuspended in $100 \mu$ l of lysis buffer (10 nм HEPES, pH 7.9,
$1.5 \mathrm{~nm} \mathrm{MgCl}_{2}, 10 \mathrm{nM} \mathrm{KCl}, 0.5 \mathrm{~mm}$ DTT, $0.5 \mathrm{~mm}$ phenylmethylsulfonyl fluoride [PMSF]) and protease inhibitors (protease inhibitor cocktail tablets; Boehringer Mannheim, Indianapolis, Indiana) (1 tablet/10 $\mathrm{ml}$ ), and incubated on ice for 4 minutes. NP-40 20\% (1 $\mu$ l) was added, and cells were vortexed for $10 \mathrm{sec}-$ onds. Nuclei were pelleted by centrifugation at 14,000 $\times g$ for 1 minute. The supernatant containing the cytoplasmic fraction was collected and stored at $-80^{\circ} \mathrm{C}$. Protein was extracted from the nuclei with extraction buffer containing $100 \mathrm{~mm}$ Tris, pH 7.4, 100 $\mathrm{mm} \mathrm{NaCl}, 1 \mathrm{~mm}$ EDTA, $1 \mathrm{~mm}$ ethyleneglycotetraacetic acid (EGTA), $1 \mathrm{~mm} \mathrm{NaF,} 20 \mathrm{~mm} \mathrm{NaP}_{2} \mathrm{O}_{4}, 2 \mathrm{~mm} \mathrm{Na}_{3} \mathrm{VO}_{4}$, $1 \%$ Triton $\mathrm{X}-100,10 \%$ glycerol, $0.1 \%$ SDS, $0.5 \%$ deoxycholate, $1 \mathrm{~mm}$ PMSF, and a protease inhibitor cocktail tablet.

\section{Western Blot Analysis}

For the experiments in Figures 2 and 8, cells were lysed in the extraction buffer. For the experiment in Figure 6, cytoplasmic and nuclear proteins were isolated by the method described above. The concentration of protein in each cell lysate was determined by means of a bicinchoninic acid assay (Pierce, Rockford, Illinois) using bovine serum albumin (BSA) as the standard. Protein extracts were mixed with an equal volume of $2 \times$ Laemmli's sample buffer (Laemmli et al, 1970). Equal amounts of each sample were loaded on a 10\% SDS-PAGE and transferred to nitrocellulose membranes using a semi-dry transblotting apparatus (Bio-Rad, Hercules, California). Nitrocellulose membranes were blocked with $5 \%$ nonfat milk in Trisbuffered saline Tween (TBST) buffer-20 mM Tris, 137 $\mathrm{mm} \mathrm{NaCl}, \mathrm{pH} 7.6$, with $0.1 \%$ Tween 20 for 60 minutes at room temperature. Blots were incubated with antiRelA or anti-tubulin at 1:1000, or anti-IL-8 antibody at 1:5000, in TBST containing $5 \%$ nonfat milk for 60 minutes. Blots were washed three times and then incubated in horseradish peroxidase (HRP)conjugated antibody (1:10,000 dilution) for 1 hour at room temperature. All blots were developed using the enhanced chemoluminescence (ECL) reagents (Amersham, Arlington Heights, Illinois) per the manufacturer's instructions. Blots were scanned and analyzed for the measurement of the band intensities with the Un-Scan-It software, version 5.1 (Silk Scientific, Orem, Utah). Band intensity corresponded to the sum of all pixel values in the segment selected minus the background pixel value in that segment. For the experiments with sense and antisense oligonucleotides to $\mathrm{NF} \kappa \mathrm{B}$ p65, the percentage of inhibition of IL-8 was calculated as follows: $([a-b] / a) \times 100$, with a corresponding to the band intensity of IL-8 produced by RA synovial fibroblasts pretreated with the sense oligonucleotide, and $b$ corresponding to the band intensity of IL-8 produced by RA synovial fibroblasts pretreated with the antisense oligonucleotide.

\section{Statistical Analysis}

Data was expressed as the mean \pm SEM. Group means were compared with a Student's paired $t$ test or a 
Wilcoxon rank order test, as appropriate. $p$ values $<0.05$ were considered statistically significant.

\section{References}

Baggiolini M, Dewald B, and Moser B (1997). Human chemokines: An update. Annu Rev Immunol 15:675-705.

Barbulescu K, Becker C, Schlaak JF, Schmitt E, Meyer zum Buschenfelde KH, and Neurath MF (1998). IL-12 and IL-18 differentially regulate the transcriptional activity of the human IFN-gamma promoter in primary CD4+ T lymphocytes. J Immunol 160:3642-3647.

Bazan JF, Timans JC, and Kastelein RA (1996). A newly defined interleukin-1. Nature 379:591.

Bombara MP, Webb DL, Conrad P, Marlor CW, Sarr T, Ranges GE, Aune TM, Greve JM, and Blue ML (1993). Cell contact between $T$ cells and synovial fibroblasts causes induction of adhesion molecules and cytokines. J Leukoc Biol 54:399-406.

Bucala R, Ritchlin C, Winchester R, and Cerami A (1991). Constitutive production of inflammatory and mitogenic cytokines by rheumatoid synovial fibroblasts. J Exp Med 173: 569-574.

Crofford LJ, Tan B, McCarthy CJ, and Hla T (1997). Involvement of nuclear factor kappa $B$ in the regulation of cyclooxygenase-2 expression by interleukin-1 in rheumatoid synoviocytes. Arthritis Rheum 40:226-236.

Dinarello CA (1999). IL-18: A TH1-inducing, proinflammatory cytokine and new member of the IL-1 family. J Allergy Clin Immunol 103:11-24.

Fantuzzi G and Dinarello CA (1999). Interleukin-18 and interleukin-1 beta: Two cytokine substrates for ICE (caspase1). J Clin Immunol 19:1-11.

Fehniger TA, Shah MH, Turner MJ, VanDeusen JB, Whitman SP, Cooper MA, Suzuki K, Wechser M, Goodsaid F, and Caligiuri MA (1999). Differential cytokine and chemokine gene expression by human NK cells following activation with IL-18 or IL-15 in combination with IL-12: Implications for the innate immune response. J Immunol 162:4511-4520.

Gracie JA, Forsey RJ, Chan WL, Gilmour A, Leung BP, Greer MR, Kennedy K, Carter R, Wei XQ, Xu D, Field M, Foulis A, Liew FY, and McInnes IB (1999). A proinflammatory role for IL-18 in rheumatoid arthritis. J Clin Invest 104:1393-1401.

Hsieh CS, Macatonia SE, Tripp CS, Wolf SF, O'Garra A, and Murphy KM (1993). Development of TH1 CD4+ T cells through IL-12 produced by Listeria-induced macrophages. Science 260:547-549.

Koch AE, Kunkel SL, Harlow LA, Mazarakis DD, Haines GK, Burdick MD, Pope RM, and Strieter RM (1994). Macrophage inflammatory protein-1 alpha. A novel chemotactic cytokine for macrophages in rheumatoid arthritis. J Clin Invest 93: 921-928.

Koch AE, Kunkel SL, and Strieter RM (1996). Chemokines in arthritis. In: Koch AE and Strieter RM, editors. Chemokines in disease. Austin: R.G. Landes, 103-116.

Koch AE, Polverini PJ, and Leibovich SJ (1986). Stimulation of neovascularization by human rheumatoid synovial tissue macrophages. Arthritis Rheum 29:471-479.

Koch AE and Strieter RM (1996). Chemokines in Disease. Austin: R. G. Landes, 103-111.
Kojima H, Aizawa Y, Yanai Y, Nagaoka K, Takeuchi M, Ohta T, Ikegami H, Ikeda M, and Kurimoto M (1999). An essential role for NF-kappa B in IL-18-induced IFN-gamma expression in KG-1 cells. J Immunol 162:5063-5069.

Kunsch C and Rosen CA (1993). NF-kappa B subunitspecific regulation of the interleukin-8 promoter. Mol Cell Biol 13:6137-6146.

Laemmli UK (1970). Cleavage of structural proteins during the assembly of the head of bacteriophage T4. Nature 227:680-685.

Leung BP, Mclnnes IB, Esfandiari E, Wei XQ, and Liew FY (2000). Combined effects of IL-12 and IL-18 on the induction of collagen-induced arthritis. J Immunol 164:6495-6502.

Matsumoto S, Tsuji-Takayama K, Aizawa Y, Koide K, Takeuchi M, Ohta T, and Kurimoto M (1997). Interleukin-18 activates NF-kappaB in murine $\mathrm{T}$ helper type 1 cells. Biochem Biophys Res Commun 234:454-457.

Moeller B, Kukoc-Zivojnov N, Kessler U, Rehart S, Kaltwasser JP, Kalina U, Hoelzer D, and Ottmann OG (1999). Enhanced expression of interleukin-18 in synovial fibroblast-like cells from patient with rheumatoid arthritis and IL-18receptor expression. Arthritis Rheum 42:S195.

Naik SM, Cannon G, Burbach GJ, Singh SR, Swerlick RA, Wilcox JN, Ansel JC, and Caughman SW (1999). Human keratinocytes constitutively express interleukin-18 and secrete biologically active interleukin-18 after treatment with pro-inflammatory mediators and dinitrochlorobenzene. J Invest Dermatol 113:766-772.

Netea MG, Fantuzzi G, Kullberg BJ, Stuyt RJ, Pulido EJ, McIntyre RC Jr, Joosten LA, Van der MJW, and Dinarello CA (2000). Neutralization of IL-18 reduces neutrophil tissue accumulation and protects mice against lethal Escherichia coli and Salmonella typhimurium endotoxemia. J Immunol 164: 2644-2649.

Okamura $\mathrm{H}$, Tsutsi $\mathrm{H}$, Komatsu T, Yutsudo M, Hakura A, Tanimoto T, Torigoe K, Okura T, Nukada Y, and Hattori K (1995). Cloning of a new cytokine that induces IFN-gamma production by T cells. Nature 378:88-91.

Olee T, Hashimoto S, Quach J, and Lotz (1999). M IL-18 is produced by articular chondrocytes and induces proinflammatory and catabolic responses. J Immunol 162:1096-1100.

Puren AJ, Fantuzzi G, Gu Y, Su MS, and Dinarello CA (1998). Interleukin-18 (IFNgamma-inducing factor) induces IL-8 and IL-1beta via TNFalpha production from non-CD14+ human blood mononuclear cells. J Clin Invest 101:711-721.

Roshak AK, Jackson JR, McGough K, Chabot-Fletcher M, Mochan E, and Marshall LA (1996). Manipulation of distinct NFkappaB proteins alters interleukin-1beta-induced human rheumatoid synovial fibroblast prostaglandin E2 formation. J Biol Chem 271:31496-31501.

Schlaak JF, Schwarting A, Knolle P, Meyer zum Buschenfelde $\mathrm{KH}$, and Mayet W (1995). Effects of Th1 and Th2 cytokines on cytokine production and ICAM-1 expression on synovial fibroblasts. Ann Rheum Dis 54:560-565.

Schwachula A, Riemann D, Kehlen A, and Langner J (1994). Characterization of the immunophenotype and functional properties of fibroblast-like synoviocytes in comparison to skin fibroblasts and umbilical vein endothelial cells. Immunobiology 190:67-92. 
Seder RA, Gazzinelli R, Sher A, and Paul WE (1993). Interleukin 12 acts directly on CD4+ T cells to enhance priming for interferon gamma production and diminishes interleukin 4 inhibition of such priming. Proc Natl Acad Sci USA 90: 10188-10192.

Seitz M, Loetscher P, Dewald B, Towbin H, and Baggiolini M (1996). Opposite effects of interleukin-13 and interleukin-12 on the release of inflammatory cytokines, cytokine inhibitors and prostaglandin E from synovial fibroblasts and blood mononuclear cells. Eur J Immunol 26:2198-2202.

Shapiro L, Puren AJ, Barton HA, Novick D, Peskind RL, Shenkar R, Gu Y, Su MS, and Dinarello CA (1998). Interleukin 18 stimulates HIV type 1 in monocytic cells. Proc Natl Acad Sci USA 95:12550-12555.

Shin H, Kitajima I, Nakajima T, Shao Q, Tokioka T, Takasaki I, Hanyu N, Kubo T, and Maruyama I (1999). Thrombin receptor mediated signals induce expressions of interleukin 6 and granulocyte colony stimulating factor via NF-kappa B activation in synovial fibroblasts. Ann Rheum Dis 58:55-60.

Suzuki M, Tetsuka T, Yoshida S, Watanabe N, Kobayashi M, Matsui N, and Okamoto T (2000). The role of p38 mitogenactivated protein kinase in IL- 6 and IL- 8 production from the TNF-alpha- or IL-1 beta-stimulated rheumatoid synovial fibroblasts. FEBS Lett 465:23-27.

Szekanecz Z, Strieter RM, Kunkel SL, and Koch AE (1998). Pathogenesis and treatment of rheumatoid arthritis: Chemokines in rheumatoid arthritis. Springer Semin Immunopathol 20:115-132.

Takeda K, Tsutsui H, Yoshimoto T, Adachi O, Yoshida N, Kishimoto T, Okamura H, Nakanishi K, and Akira S (1998). Defective NK cell activity and Th1 response in IL-18-deficient mice. Immunity 8:383-390.

Torigoe K, Ushio S, Okura T, Kobayashi S, Taniai M, Kunikata T, Murakami T, Sanou O, Kojima H, Fujii M, Ohta T, Ikeda M, Ikegami H, and Kurimoto M (1997). Purification and characterization of the human interleukin-18 receptor. J Biol Chem 272:25737-25742.
Udagawa N, Horwood NJ, Elliott J, Mackay A, Owens J, Okamura $\mathrm{H}$, Kurimoto $\mathrm{M}$, Chambers TJ, Martin TJ, and Gillespie MT (1997). Interleukin-18 (interferon-gammainducing factor) is produced by osteoblasts and acts via granulocyte/macrophage colony-stimulating factor and not via interferon-gamma to inhibit osteoclast formation. J Exp Med 185:1005-1012.

Wu GD, Lai EJ, Huang N, and Wen X (1997). Oct-1 and CCAAT/enhancer-binding protein (C/EBP) bind to overlapping elements within the interleukin-8 promoter. The role of Oct-1 as a transcriptional repressor. J Biol Chem 272:23962403.

Yasumoto K, Okamoto S, Mukaida N, Murakami S, Mai M, and Matsushima K (1992). Tumor necrosis factor alpha and interferon gamma synergistically induce interleukin 8 production in a human gastric cancer cell line through acting concurrently on AP-1 and NF-kB-like binding sites of the interleukin 8 gene. J Biol Chem 267:22506-22511.

Yoshimoto T, Okamura H, Tagawa YI, Iwakura Y, and Nakanishi K (1997). Interleukin 18 together with interleukin 12 inhibits IgE production by induction of interferon-gamma production from activated B cells. Proc Natl Acad Sci USA 94:3948-3953.

Yoshimoto T, Takeda K, Tanaka T, Ohkusu K, Kashiwamura S, Okamura H, Akira S, and Nakanishi K (1998). IL-12 up-regulates IL-18 receptor expression on T cells, Th1 cells, and B cells: Synergism with IL-18 for IFN-gamma production. J Immunol 161:3400-3407.

Zhang T, Kawakami K, Qureshi MH, Okamura H, Kurimoto M, and Saito A (1997). Interleukin-12 (IL-12) and IL-18 synergistically induce the fungicidal activity of murine peritoneal exudate cells against Cryptococcus neoformans through production of gamma interferon by natural killer cells. Infect Immun 65:3594-3599.

Zhu Z, Tang W, Gwaltney JM Jr, Wu Y, and Elias JA (1997). Rhinovirus stimulation of interleukin-8 in vivo and in vitro: Role of NF-kappaB. Am J Physiol 273:L814-L824. 